\title{
Factors Affecting the Local Governments Financial Performance
}

\author{
Regita Oktaviani, Satria Yudhia Wijaya, Ermawati \\ Universitas Pembangunan Nasional Veteran Jakarta, Indonesia \\ ermawati@upnvj.ac.id
}

\begin{abstract}
This study aims to test and prove the relationship of local government financial performance with fiscal balance transfer, local own-source revenue, local government size, and capital expenditure. The study uses samples from District/City Local Governments in Sulawesi Island for the years 2016-2018. The samples were collected using the census sampling method, for a total of 243 samples in District/City Local Governments in Sulawesi Island. In this analysis, the hypothesis testing is performed using SPSS by the multiple linear regression method. The result of this study shows that fiscal balance transfer has a negative impact on the local government financial performance, local own-source revenue has an impact towards the local government financial performance, local government size does not have an effect towards the local government financial performance, and capital expenditure has an effect towards the local government financial performance. This study is expected to contribute to local governments by providing recommendations to improve the local government financial performance.
\end{abstract}

Keywords: Fiscal balance transfer, Local own-source revenue, Local government size, Capital expenditure, financial performance.

\section{Introduction}

Improvement of performance must be done, by both private and public organizations. The performance of private organizations differs from the public sector, in which majority of performance measurement is based on revenue, and the public sector does not use revenue as a measurement for the success of an organization, since its main objective is not to generate revenue, but to improve the welfare of the people, as well as public services. The performance of local governments can be viewed from a financial viewpoint, through financial, performance to determine the efficiency and effectivity in managing local finances (Putri \& Aswar, 2020). According to Mardiasmo (2009), public sector performance can be measured using value for money, which consists of economy, efficiency, and effectivity. This study is not in line with Andani and Respati (2019), and consistent with study carried out by (Mulyani \& Wibowo 2017). The examination of performance is aimed to assess the 3E aspects (economy, efficiency, and effectivity). The performance examination result report of the BPK concludes that performance is still not generally effective. In Districts/Cities in Sulawesi Island, the BPK implemented the following examinations related to performance examination in Districts/Cities from 6 provinces.

Table 1: Performance Examination

\begin{tabular}{lll}
\hline Entity & Number of Examinations & Examination Result \\
\hline North Bolaang Mongondow District & 1 & Not Yet Effective \\
Minahasa District & 1 & Ineffective \\
North Minahasa District & 1 & Ineffective \\
Manado City & 1 & Not Yet Effective \\
Poso District & 1 & Not Yet Effective \\
Barru District & 1 & Not Yet Effective \\
Selayar Islands District & 1 & Not Yet Effective \\
Maros District & 1 & Ineffective \\
Soppeng District & 1 & Ineffective \\
Wakatobi District & 1 & Not Yet Effective \\
Mamasa District & 1 & Not Yet Effective \\
Gorontalo District & 1 & Not Yet Effective \\
Gorontalo City & 1 & Ineffective \\
Total & 13 & \\
\hline
\end{tabular}


Based on Table 1, which summarize the examination result for several Districts/Cities in the Sulawesi Island the BPK still states that performances are still not yet effective or ineffective. The performance of local governments are achievements of vision, mission, as well as the goal of activities listed in local planning document, which will later impact the welfare of the people, as well as improve the quality of public services. The government must improve financial performance in managing local finances. Previous studies have frequently discusses factors affecting the local government financial performance, such as the study Aminah et al. (2019) which states that fiscal balance transfer has an effect on the local governments financial performance, in which the higher the fiscal balance transfer, the more funds that are received to fund local government activities in promoting the welfare of the people, improving public services, and improve the local government's performance itself. The existence of funds from the central government may function to increase the influence of the central government in implementing closer monitoring towards the disclosure of public sector financial reports (Ingram \& DeJong, 1987). Furthermore, the local government financial performance may be affected by local own-source revenue. Aswar (2019), and Apridiyanti (2019) found that local own-source revenue has an positive effect on the local governments financial performance, which is indicates that higher the independence of the region, and avoids funding dependence from the central government. Therefore, is able to use self-generated funds to increase the growth of the people and thus increases the local government performance.

Another factor that can affect the local government financial performance is local government size. Governments will display good news in order to obtain a higher performance score, based on the study conducted by Tama and Adi (2018). Local government size in this study is used based on previous research conducted by (Aswar, 2019). The research conducted by Mulyani and Wibowo (2017) states that local government size has an effect on the local government's financial performance. Capital expenditure is another factor that can affect the financial performance of local governments. Mulyani and Wibowo (2017) stated that capital expenditure has a positively significant on the local government's financial performance. The higher the allocation of capital expenditure, the better the local government financial performance. This is due to the fact that local expenditure is the expenditure of the government in order to provide services to the people, who will experience direct or indirect impact (Andirfa et al., 2016). Capital expenditure is made by the government for things such as infrastructure building, as well as other types of building (Ermawati \& Aswar, 2020). Therefore, the aim of this study is to investigate the relationship between fiscal balance transfer, local own-source revenue, local government size, and capital expenditure towards the financial performance of local governments.

\section{Literature Review and Hypothesis Development}

Agency Theory: Harahap (2011) explains that the agency theory is a relationship between the management, owner, creditors, and the government. In the implementation of relationships between the investor and management of a business, agency relationships frequently occur, according to Jensen and Melking (1976). Furthermore, Sochib (2016) explains that the agency relationship is a contract that consists of one or more parties, called the principal, who employs another party, which is the agent, to accomplish several services, and afterwards delegates decision-making authority to the agent.

Signaling Theory: According to Spence (1973), the signaling theory is a theory in which the party of the information owner attempts to provide relevant information that can be utilized by the receiver of information. The receiving party then adjusts its behavior based on the understanding of the signal. In the context of signaling, the government attempts to provide a good signal for the people (Evans \& Patton, 1987; Verawaty, 2017). The objective of this is so that the people will support the government, in order for the government to be able to be executed well, in which financial reports are one of the facilities in providing signals to the people (Verawaty, 2017).

Hypothesis and Conceptual Framework: The hypothesis development in this study is based on factors suspected to have effects towards levels of corruption, and is thus formulated as follows:

The Effect of Fiscal Balance Transfer Towards Local Government Financial Performance: Fiscal balance transfers are funds distributed by the central government to the regional governments that are used to 
finance programs in the region, to achieve the goal of the local government, to attain the local government's goal of promoting people's welfare and enhancing the quality of public services. The central government acts as the principal in relation to the agency theory, and local $g$ and the local government acts as the agent, in which the central government delegates authority to the local government in managing the finances from received funds, and the local government must assume responsibility on behalf of that authority by managing finances well, an also optimally and fairly increase the quality of public services. This will improve the local government's financial efficiency, based on studies conducted by Andirfa et al. (2016) and Awwaliyah et al. (2019), which show that fiscal balance transfer has a positive effect on the financial performance of local governments. The hypothesis is formulated on the basis of the explanation above:

H1: Fiscal Balance Transfer positively significant on the Local Governments Financial Performance.

The Effect of Local Own-Source Revenue Towards Local Government Financial Performance: Local own-source revenue is revenue retrieved from the region itself, based on regulations that apply, originating from local tax, local retribution, and other lawful revenue. In the context of the agency theory, the people act as the principal by providing funding for local retributions, and the local government acts as the agent, who executes responsibility in managing its funds, which originate from the people, to drive other activities in order to achieve the goal of the organization. Andrei (2013), Aswar (2019) and Awwaliyah et al. (2019) found that local own-source revenue positively significant on the local governments financial performance. Therefore, the hypothesis formulated:

H2: Local Own-Source Revenue positively significant on the Local Governments Financial Performance.

The Effect of Local Government Size Towards Local Government Financial Performance: Size of local government determines the size of the region. This is one of the recommendations from the study conducted by (Aswar, 2019). Local government size is viewed from the number of citizens, in which every district/city has a different number of citizens and budget. A higher number of citizens will trigger local governments to send signals or relevant information related to the prepared financial statements, in which a good financial report indicates that an organization is running well (Sukarmi \& Budiasih, 2016), and therefore increases the local government financial performance itself. The local government's sending of signals to the people would encourage them to support the improvement of the local government's financial performance. A high amount of citizens will improve the local government performance (Mulyani \& Wibowo, 2017). This is consistent with studies carried out by Dewata et al. (2017), and Anggraini et al. (2019) found that the size of local government has a positive significant impact on the financial performance of local governments.

H3: Local Government Size positively significant on the Local Governments Financial Performance.

The Effect of Capital Expenditure Towards Local Government Financial Performance: Capital expenditure is the expenditure for development, in the form of investment for a region, which has a benefit of more than one year, and can add to the assets or wealth of the region, such as the purchase of equipment, and construction of infrastructure, which will support people's health and boost the quality of public services later. Capital Expenditure must also be done effectively and efficiently, in which local governments must spend low costs in order to produce optimal output and later provide positive impact towards the people. In the context of the signaling theory, capital expenditure is one of the way that the local government sends signals to the people regarding expenditures of the local government in the form of relevant capital expenditure, in order for the people to use this information and support the improvement of local government financial performance in the capital expenditure aspect, since it can be directly or indirectly felt by the people in forms such as facilities and infrastructure construction, which will improve the quality of public services. Good management and financial reports indicate that an organization is running well (Sukarmi \& Budiasih, 2016). A high capital expenditure indicated good local government performance. This is in line with the studies conducted by Andirfa et al. (2016), and Leki (2018), which state that capital expenditure has a positive significant effect on the local governments financial performance.

H4: Capital Expenditure positively significant on the Local Governments Financial Performance.

\section{Research Methodology}

This study uses the financial reports of District/City Local Governments financial report for 2016-2018 on Sulawesi Island for 243 Districts/Cities. SPSS had evaluated theories using multiple linear regression 
methods. The dependent variable in this analysis is local government financial performance, measured using the rate of efficiency adopted by (Mulyani \& Wibowo, 2017). The independent variables in this study are: fiscal balance transfer measured using the total realization of fiscal balance transfer, local own-source revenue measured using the total realization of local own-source revenue, size of local government measured using the total revenue in comparison to the number of citizens, and capital expenditure, measured using the total realization of capital expenditure, based on the study conducted by (Mulyani \& Wibowo, 2017).

\section{Results and Discussion}

This study using the saturated sampling method, 243 samples were taken from 81 districts/cities for a 3 years duration. However, in this analysis, only 185 samples were used after removal of outlier results. In the descriptive statistics found in Table 2, the independent variable of fiscal balance transfer has an average value of 27.3772, average local own-source revenue is 24.9595, local government size has an average value of 15.4383, and capital expenditure has an average value of 26.2176. Meanwhile the dependent variable, financial performance has an average value of 0.8690 . The standard deviation the financial performance is $0.05212>0$. Therefore, it can be concluded that all the data in this study is variative or not uniform. The standard deviation for the independent variables, fiscal balance transfer is $0.29352>0$, local own-source revenue is $0.87545>0$, local government size is $0.37500>0$, and capital expenditure is $0.34294>0$, therefore, it can be concluded that all the data in this study is variative or not uniform.

Table 2: Descriptive Statistics

\begin{tabular}{llllll}
\hline & N & Minimum & Maximum & Mean & Std. Deviation \\
\hline FPLG & 185 &, 76 & 1,03 &, 8690 &, 05212 \\
FBT & 185 & 26,72 & 28,32 & 27,3772 &, 29352 \\
LOSR & 185 & 22,86 & 27,95 & 24,9595 &, 87545 \\
LGS & 185 & 14,60 & 16,62 & 15,4383 &, 37500 \\
CE & 185 & 25,31 & 27,34 & 26,2176 &, 34294 \\
Valid N & 185 & & & & \\
\hline
\end{tabular}

The t-Test aims to identify the effect of each individual variable, which are fiscal balance transfer, local ownsource revenue, local government size, and capital expenditure towards the local government's financial performance in Districts/Cities in Sulawesi Island. Based on this result, it can be inferred that local ownsource revenue has an impact on local government financial performance. The results of the t-Test are found in Table 3, which shows the result of the testing of the fiscal balance transfer, local government size, local own-source revenue, and capital expenditure variables towards the financial performance of local governments in Districts/Cities in Sulawesi Island. Therefore, it can be concluded that there is an effect between capital expenditure and the local government financial performance. This study uses $\alpha=5 \%$. The result of the regression test shows that individually, fiscal balance transfer has a coefficient value of -6.477 with a significance probability of 0.000 . Based on this result, it can be concluded that fiscal balance transfer has a negative effect towards the financial performance of local governments in Districts/Cities in Sulawesi Island. This study is consistent with the theory of agencies, which states that local governments must disclose the receipt effective management of funds to the central government, promote people's welfare and enhance the quality of public services, which in effect will improve the financial performance of local government.

Table 3: Multiple Regression Analysis

\begin{tabular}{llllll}
\hline & \multicolumn{2}{l}{ Unstandardized Coefficients } & \multicolumn{2}{l}{$\begin{array}{l}\text { Standardized } \\
\text { Coefficients Beta }\end{array}$} & \\
\cline { 2 - 4 } Model & B & Std. Error & & T & Sig. \\
\hline (Constant) &, 928 &, 505 & & 1,837 &, 068 \\
Fiscal Balance Transfer &,- 129 &, 020 &,- 721 & $-6,477$ &, 000 \\
Local Own-Source Revenue &, 027 &, 006 &, 453 & 4,459 &, 000 \\
Local Government Size &,- 019 &, 013 &,- 141 & $-1,497$ &, 136 \\
BelanjaModal &, 114 &, 011 &, 753 & 10,380 &, 000 \\
\hline
\end{tabular}


The local own-source revenue has a measured t value of 4.459 with a probability value of 0.000 . The findings of this study are consistent with analysis carried out by Mulyani and Wibowo (2017), which states that a higher local-own source revenue would boost financial performance. It is also in line with the theory used in this study, which is the agency theory, in which this local own-source revenue is revenue received from the people or stakeholders towards the local government. In this context, the local government must be responsible in efficiently managing finances in order to improve the local government financial performance. The calculated $t$ value of the local government size variable is -1.497 with a significance probability of 0.136 , which is larger than the significance rate of $5 \%$. Therefore, it can be inferred that the size of local government size has no impact on local government financial performance. The findings of this study are inconsistent with study conducted by Mulyani and Wibowo (2017), and are consistent with the study conducted by (Dewata et al., 2017). The result of this analysis does not adhere to the signaling theory, which states that the size of a local government is determined using. The number of citizens and revenue budget in Districts/Cities in the Sulawesi Island, and therefore cannot yet be reported as a factor affecting a local government's financial performance.

A local government with a low number of citizens might not have bad financial performance, since governments with a small number of citizens must also improve the quality of services for the people. This study is not consistent with the signaling theory, in which the government would send financial management signals to the people, as people are more focused on direct impacts or outcomes that people may feel directly. Capital expenditure has a coefficient value of 10.380 with a significance probability of 0.000 , which is less than the significance rate of 5\%. This study is not in line with Andani and Respati (2019), and consistent with study carried out by (Mulyani \& Wibowo 2017). This study consistent with the signaling theory, since a high capital expenditure indicates the construction of many facilities and infrastructure, which will be directly felt by the people, and the more designed infrastructures would increase the efficiency of public services, and local government financial performance. The local government sends signals to the people regarding expenditures made by the government in the form of capital expenditure, which can be directly felt by the people and therefore support the local government financial performance.

\section{Conclusion}

The aim of this study is to investigate the impact of fiscal balance transfer, local own-source revenue, local government size, and capital expenditure on the financial performance of local government. The following finding can be derived from this study after review and hypothesis testing: fiscal balance transfer have a negative effect on the local governments financial performance, local own-source revenue and capital expenditure have a positive impact on the financial performance of local governments. Meanwhile, local government size does not have relationship towards the local government's financial performance. The implications of this study in practice is to make a commitment to local governance as the engine of financial performance in local governments in order to be able to pay attention to policy and low problems and be able to enhance and raise the budget financial efficiency more effectively and efficiently. Local governments should be stable in managing their pure local revenue and be able to handle economically derived external funds. To obtain the confidence of the communities, the National Audit Board will issue a credible audit opinion which will enhance the local governments of financial performance. Further analysis to extend the objects of the study in order to be able to generalize, as well as utilize other theories and measurements besides the variables used in this study, especially the local government size variable, audit opinion and intergovernmental revenue, and to increase the sample size in order to achieve better results.

\section{References}

Aminah, I. N., Afiah, N. N. \& Pratama, A. (2019). Pengaruh size, wealth, intergovermental revenue dan belanja modal terhadap kinerja pemerintah daerah. Jurnal SIKAP (Sistem Informasi, Keuangan, Auditing dan Perpajakan), 3(2), 147-165.

Andani, M., Sarwani. \& Respati, N. W. (2019). The effects of the characteristics of local Goverments and audit opinions on the performance of provincial goverments in Indonesia. Jurnal Akuntansi, 9(1), 111-130.

Andirfa, M., Basri, H., Com, M., Shabri, M., Majid, A. \& Ec, M. (2016). Pengaruh belanja modal, dana perimbangan dan pendapatan asli daerah terhadap kinerja keuangan kabupaten dan kota di Provinsi 
Aceh. Jurnal Magister Akuntansi, 5(3), 30-38.

Andrei, P. (2013). The analysis of the financial performance of local authorities in the context of budgetary constraints. Management \& marketing challenges for the knowledge society. Univesity of Lasi, 18(3), 553-574.

Anggraini, L., Rahayu, S. \& Junaidi. (2019). Pengaruh karakteristik pemerintah daerah terhadap kinerja pemerintah daerah (Studi pada pemerintah Kabupaten/Kota di Provinsi Jambi), 4(1), 45-56.

Apridiyanti, A. (2019). Pengaruh pendapatan asli daerah terhadap kinerja keuangan pemerintah daerah Kabupaten dan Kota di Jawa Barat 2013-2017. Jurnal Akuntansi \& Ekonomi FE. UN PGRI Kediri, 4(3), 32-41.

Aswar, K. (2019). Financial performance of local governments in Indonesia. European Journal of Business and Management Research, 4(6), 1-6.

Awwaliyah, N. F., Agriyanto, R. \& Farida, D. N. (2019). The effect of regional original income and balance funding on regional government financial performance. Journal of Islamic Accounting and Finance Research, 1(1), 25-46.

Dewata, E., Ilmiyyah, N. M. \& Sarikadarwati, S. (2017). Faktor-faktor yang mempengaruhi kinerja keuangan Pemerintah Kabupaten/Kota di Provinsi Sumatera Selatan tahun 2012-2015. Jurnal Akuntansi, Ekonomi dan Manajemen Bisnis, 5(1), 147-162.

Ermawati, E. \& Aswar, K. (2020). Assessing regional finance independence in Indonesian local governments. European Journal of Business and Management Research, 5(1), 1-5.

Evans \& Patton. (1987). Signaling and Monitoring in Public Sector Accounting. Journal of Accounting Research, 130-158.

Harahap, S. S. (2016). Teori akuntansi. Edisi revisi 2011. PT Raja Grafindo Persada.

Ingram, R. W. \& DeJong, D. V. (1987). The effect of regulation on local government disclosure practices. Journal of Accounting and Public Policy, 6(4), 245-270.

Jensen, M. C. \& Meckling, W. H. (1976). Theory of the firm: Managerial behavior, agency costs and ownership structure. Journal of Financial Economics, 3(4), 305-360.

Leki, Y. (2018). Pengaruh pendapatan asli Daerah dan belanja modal terhadap kinerja keuangan pada pemerintah kabupaten Halmahera Barat. Jurnal Berkala Ilmiah efisiensi, 18(5), 164-174.

Mardiasmo. (2009). Akuntansi Sektor Publik, Yogyakarta: Andi.

Mulyani, S. \& Wibowo, H. (2017). Pengaruh belanja modal, ukuran pemerintah daerah, intergovermental revenue, dan pendapatan asli daerah terhadap kinerja keuangan (Kabupaten/Kota di Provinsi Jawa Tengah, tahun 2012-2015). Jurnal Ilmiah Akuntansi, 17(1), 57-66.

Putri, L. E. \& Aswar, K. (2020). Performance measurement of local government in Indonesia: A conceptual study. Information Management and Business Review, 12(1), 41-44.

Sochib. (2016). Pengaruh capital adequacy ratio, debt to equity ratio, rasio biaya operasional pendapatan operasional, dan loan to deposit ratio terhadap kinerja keuangan bank umum swasta nasional. Jurnal penelitian ilmu ekonomi wiga, 6(1), 1-14.

Spence, M. (1973). Job market signaling. The Quartely Journal of Economics, 87(3), 355-374.

Sukarmi, N. W. \& Budiasih, I. N. (2016). Kinerja keuangan pada pertumbuhan ekonomi Kabupaten/Kota di Provinsi Bali. E-Jurnal Ekonomi dan Bisnis Universitas Udayana, 5(3), 545-572.

Tama, I. M. A. T. \& Adi, P. H. (2018). Pengaruh karakteristik kepala daerah, ukuran pemerintah, dan temuan audit terhadap kinerja keuangan daerah, Perspektif Akuntansi, 1(1), 91-113.

Verawaty. (2017). Determinan transparasi informasi keuangan pemerintah melalui e-goverment pemerintah daerah di Sumatera Selatan. Journal of Accounting and Finance, 13(2), 92-107. 